\title{
Influence of Stabilized Biosolids Application on Availability of Phosphorus, Copper, and Zinc
}

\author{
S. M. Shaheen, M. S. Shams, F. A. Elbehiry, and S. M. Ibrahim \\ Department of Soil Sciences, Faculty of Agriculture, University of Kafrelsheikh, Kafr El-Sheikh 33516, Egypt \\ Correspondence should be addressed to S. M. Shaheen, smshaheen1973@yahoo.com
}

Received 6 February 2012; Revised 18 April 2012; Accepted 7 June 2012

Academic Editor: Alejandro Valdecantos

Copyright () 2012 S. M. Shaheen et al. This is an open access article distributed under the Creative Commons Attribution License, which permits unrestricted use, distribution, and reproduction in any medium, provided the original work is properly cited.

The main aim of this study was to examine the influence of sewage sludge (SS) and stabilized SS application on Olsen-P and DTPA-extractable $\mathrm{Cu}$ and $\mathrm{Zn}$ in relation to soil type, sewage source, mixing rate and incubation time. Two different SS were mixed with amendments by mixing rates 10 and $25 \%$. These amendments include coal fly ash (CFA), bentonite (B), sugar beet factory lime (SBFL), calcium carbonate, rice straw (RS), water hyacinth (WH), and cotton stalks (CS). Treated and untreated SS had been applied to fluvial and calcareous soil with application rate $2.5 \%$ and incubated for one and two month. After incubation, soil samples were analyzed for Olsen-P and DTPA-extractable Cu and Zn. Application of SS increased significantly Olsen-P and DTPA extractable $\mathrm{Cu}$ and $\mathrm{Zn}$ compared to control. Application of stabilized SS increased significantly Olsen-P, with high increasing rate with SBFL and WH-stabilized SS. Stabilized-SS decreased significantly $\mathrm{Cu}$ and $\mathrm{Zn}$ availability compared to mono SS treatment. Bentonite-, SBFL and CFA-stabilized SS were the highest among inorganic treatments for reducing available Cu and $\mathrm{Zn}$ either in fluvial or calcareous soil, while WH and RS-stabilized SS treatment were the most suitable organic ones for reducing DTPAextractable $\mathrm{Cu}$ and $\mathrm{Zn}$.

\section{Introduction}

Waste management is recognized as an important issue in modern societies, and waste recycling is encouraged as an alternative to stockpiling and incineration. The application of sewage sludge or composts of several origins as amendments to agricultural soils is an economically attractive waste management strategy promoted by scientists and regulating organisms and is a common practice since many years $[1,2]$. Improvement of soil properties is among the benefits of sewage-sludge application to agricultural land. In association with its high organic matter content, sludge contains also appreciable amounts of macro- and micronutrients with significant fertilizer replacement value [1]. These beneficial effects make sludge application an attractive option for eroded soils of dry Mediterranean climates that usually have low organic matter content. However, land application of SS has been limited by its enriched pathogens and heavy metal contents. Excessive levels of trace elements introduced to soil by SS can lead to elevated uptake of trace elements by plants, which will cause damage to plants and effects on human health upon consumption of crops grown on the soil [3]. So, the study of effective methods for trace element removal from sludge is very important in order to minimize prospective health risk after application.

Recently, increased attention was paid to the sludge stabilization/immobilization process aiming to minimize the mobility of trace elements by using various additives, due to compliance to more stringent regulations issue in USA and European Union. Stabilization/immobilization refers to techniques that chemically reduce the hazardous potential of a waste by converting the contaminants into less soluble, mobile, or toxic forms. Sewage sludge can be treated in a matrix of different organic and inorganic materials $[4,5]$.

Among the different macronutrients contained in sludge phosphorus is an essential element for plant metabolism since it is present in numerous molecules such as phospholipids or nucleotides. For this reason $\mathrm{P}$ is often considered one of the most limiting nutrients for plant productivity. Comparable quantities of sludge cakes are commonly applied to degraded soils in the Mediterranean areas. These rates, however, exceed crop nutrients requirements and may cause 
undesirable changes in soil chemical properties, leading to environmental contamination. Such effects include accumulation of $\mathrm{P}$ which can impact water bodies through surface run-off leaching which in turn may threaten surface and ground waters through eutrophication [6]. So, the effective soil phosphorus management from both environmental and agronomic point of view requires the knowledge of $\mathrm{P}$ bioavailability [7-10].

Copper and zinc are essential elements for higher plants but at the same time potentially environmental contaminants. Copper and zinc may enter the soil through fertilizer, organic wastes, and pesticides applications. Sewage sludge usually contains significant amounts of $\mathrm{Cu}$ and $\mathrm{Zn}$ and can be a source of these two metals in the soil [11].

The availability of $\mathrm{P}$ and trace elements present in the sewage sludge depends on many factors such as the nature and amount of element, degree of element association in the sludge, sewage source, application rate, soil type, plant characteristics, and weather conditions $[8,10]$.

Although several studies have dealt with the possible increase of available $\mathrm{P}$ and trace elements arising through land application of SS [10, 12-15], little work has been done on the potential changes in their availability through its application with stabilized SS to soil differing widely in their properties. In Egypt, management of the large quantities of sewage sludge produced from sewage treatment plants and some environmental wastes, that is, sugar beet factory lime, brick factory fly ash, rice straw, and water hyacinth, is a serious problem since, so far, its agricultural use remains at very low levels. However, a sound alternative for these wastes would be their agronomic utilization. Although enough research has been carried out on the agricultural use of sewage sludge [16], relevant work on the agricultural utilization of sugar beet factory lime, fly ash, rice straw, and water hyacinth especially used together with SS as stabilized sewage sludge using these amendments is very limited. Therefore, the aim of this study was to examine the influence of SS from two different sources and stabilized sludge with different organic and inorganic amendments on Olsen-P and DTPA-extractable $\mathrm{Cu}$ and $\mathrm{Zn}$ in an incubation experiment in relation to soil type, sewage source, mixing rate, and incubation time.

\section{Materials and Methods}

\subsection{Selection and Preparation of Soil, Sewage Sludge, and Amendments Samples}

2.1.1. Soil Samples. Surface $(0-30 \mathrm{~cm})$ soil samples of cultivated Entisols (Typic Torrifluvents) developed on fluvial sediments and Aridisols (Typic Calcorthids) developed on calcareous sediments [17] were selected for this study. The fluvial soil was selected from the faculty of agriculture farm at Sakha city, Kafr el-Sheikh Governorate, and it was cultivated with wheat. The calcareous soil sample was collected from a farm in Ahmed Oraby village, Abo Elmatamer district, Elbehira Governorate, and it was cultivated with clover. The soils were air-dried and crushed to pass through a $2 \mathrm{~mm}$ sieve, eliminating stones, roots, and fragments. The dried samples were stored at room temperature in plastic bags to be ready for carrying experiments and chemical analyses.

2.1.2. Sewage Sludge Samples. Two anaerobic digested sewage sludge samples were used; the first one (SS1) was collected from Kafr EL-Zayate wastewater treatment plant, which received sludge from both domestic and industrial sources. The second one (SS2) was collected from Messer wastewater treatment plant, Kafr el-Sheikh, which received sludge from both domestic and industrial sources with dominance of domestic. The sewage sludge samples were air-dried and passed through a $2 \mathrm{~mm}$ sieve.

2.1.3. Amendments Samples. Fly ash samples (CFA) collected from the electrostatic precipitator of a lignite-fired electric power plant in Northern Greece. Sugar beet factory lime (SBFL) was obtained from the sugar beet factory of the city of El Hamoul, Kafr el-Sheikh Governorate. Bentonite (B) is a calcium saturated clay mineral with a high sorption capacity was used in this study. Calcium carbonate $\left(\mathrm{CaCO}_{3}\right)$ is a chemical reagent with $90 \%$ purity. Rice straw (RS) is dried and grinded rice residual plants. Cotton sticks (CS) are residuals of cotton plants, dried and grinded. Water hyacinth (WH) is a vascular floating aquatic plant, fast growing with a well-developed fibrous root system and large biomass. These plants were collected from fresh water pathway, dried, and grinded.

2.2. Incubation Experiment. The influence of SS and the stabilized SS on soil properties, Olsen P and DTPA-extractable amounts of $\mathrm{Cu}$ and $\mathrm{Zn}$ in relation to soil types, sewage source, mixing rate, and incubation period was investigated in an incubation experiment in which alkaline fluvial and calcareous soils were used. An incubation experiment was conducted using the studied soils and sewage at room temperature and field capacity moisture content for 30 and 60 days as follows.

\subsubsection{Stabilization of Sewage Sludge Using the Studied Amend-} ments. Stabilized sewage sludge was prepared by mixing the sludge with the amendments at two rates $(10 \%$ and $25 \%$ ) as shown in Table 1 . The SS and stabilized sewage sludge were applied to the studied soils by an application rate of $2.5 \%$ which is equivalent to $50 \mathrm{Mg}$ per hectare. The treated soils were wetted with deionized water to field capacity and incubated at room temperature. All treatments included three replicated samples $(n=3)$. The samples were incubated for 30 and 60 days. After each incubation period, the samples were air-dried, grinded to pass through a $2 \mathrm{~mm}$ sieve, and analyzed for selected chemical characteristics, Olsen-P and DTPA-extractable copper and zinc.

2.3. Analyses of Soil, Sewage Sludge, and Amendments. The following chemical properties were determined in sieved samples: $\mathrm{pH}$ in deionized water in soil solution ratio of $1: 1$ for soil and inorganic amendments and $1: 5$ for sewage sludge and organic amendments according to [18]. Total calcium carbonate equivalent (TCCE) was determined by using 
TABLe 1: Treatments of sewage sludge with the studied stabilized agents.

\begin{tabular}{lccc}
\hline Codes & Treatments & $10 \%$ & Mixing rate \\
\hline $\mathrm{SS}$ & Sewage sludge & $100 \mathrm{~g}$ & $100 \mathrm{~g}$ \\
$\mathrm{SS}+\mathrm{B}$ & Sewage sludge + bentonite & $90 \mathrm{~g} \mathrm{SS}+10 \mathrm{~g} \mathrm{~B}$ & $75 \mathrm{~g} \mathrm{SS}+25 \mathrm{~g} \mathrm{~B}$ \\
$\mathrm{SS}+\mathrm{SBFL}$ & Sewage sludge + sugar beet factory lime & $90 \mathrm{~g} \mathrm{SS}+10 \mathrm{~g} \mathrm{SBFL}$ & $75 \mathrm{~g} \mathrm{SS}+25 \mathrm{~g} \mathrm{SBFL}$ \\
$\mathrm{SS}+\mathrm{CFA}$ & Sewage sludge + coal fly ash & $90 \mathrm{~g} \mathrm{SS}+10 \mathrm{~g} \mathrm{CFA}$ & $75 \mathrm{~g} \mathrm{SS}+25 \mathrm{~g} \mathrm{CFA}$ \\
$\mathrm{SS}+\mathrm{CaCO}_{3}$ & Sewage sludge + calcium carbonate & $90 \mathrm{~g} \mathrm{SS}+10 \mathrm{~g} \mathrm{CaCO}$ & $75 \mathrm{~g} \mathrm{SS}+25 \mathrm{~g} \mathrm{CaCO}$ \\
$\mathrm{SS}+\mathrm{RS}$ & Sewage sludge + rice straw & $90 \mathrm{~g} \mathrm{SS}+10 \mathrm{~g} \mathrm{RS}$ & $75 \mathrm{~g} \mathrm{SS}+25 \mathrm{~g} \mathrm{RS}$ \\
$\mathrm{SS}+\mathrm{WH}$ & Sewage sludge + water hyacinths & $90 \mathrm{~g} \mathrm{SS}+10 \mathrm{~g} \mathrm{WH}$ & $75 \mathrm{~g} \mathrm{SS}+25 \mathrm{~g} \mathrm{WH}$ \\
$\mathrm{SS}+\mathrm{CS}$ & Sewage sludge + cotton stalks & $90 \mathrm{~g} \mathrm{SS}+10 \mathrm{~g} \mathrm{CS}$ & $75 \mathrm{~g} \mathrm{SS}+25 \mathrm{~g} \mathrm{CS}$ \\
\hline
\end{tabular}

a Collins calcimeter. Organic matter content was determined by the Walkley-Black method in soil samples [19] and by dry ashing method in sewage sludge sample. Available P was extracted by $0.5 \mathrm{M} \mathrm{NaHCO}_{3}$ according to [20]. Phosphorus content in the solutions was determined colorimetrically by using the ammonium molybdate-ascorbic acid method as described by [21]. Total trace elements were extracted by a solution of concentrated nitric acid, concentrated hydrochloric acid, and 30\% hydrogen peroxide according to [22]. Available trace elements were extracted by using diethylene triaminepentaacetic acid (DTPA) method according to [23]. The values of studied trace elements were determined by atomic absorption spectrometry (Varian, SpectrAA-400 Plus, Australia). Particle size analysis was performed according to [24].

2.3.1. Statistical Analyses. All results were analyzed statistically using one-way ANOVA to compare the means of different treatments. The individual means were compared by Duncan's test to a level of 5\% using SPSS version 10.01 . The results were subjected to multifactorial analysis. The considered variables were soil, sewage sludge, incubation period, maxing rate, and organic and inorganic amendments where $F$-test was significant at a 0.05 probability level using the JMP 10 software (SAS Institute Cary, NC, USA).

\section{Results and Discussion}

\subsection{Characterization of Studied Soils, Sewage Sludge, and Amendments Samples}

3.1.1. Soil Samples. Both studied soils showed a neutral $\mathrm{pH}$. The soils exhibited quite different physical and chemical properties (Table 2). The diverse geological nature of these deposits is reflected in the wide variation of the different physicochemical properties and amounts of total and available trace elements [25]. In general, fluvial soil exhibited total amounts of all elements except for Cd higher than the calcareous one. Also, fluvial soil showed high concentrations of DTPA-extractable $\mathrm{Cu}, \mathrm{Ni}$, and $\mathrm{Pb}$ compared to fluvial soil, while the opposite trend was recorded for DTPA-Zn and Olsen-P (Table 2). However, the total concentrations of all the studied elements were found to be lower than the critical concentrations in soils as referred by [3] or the allowable cumulative loading rates of European and US regulations $[5,26]$.

3.1.2. Sewage Sludge Samples. Kafr El-Ziat sludge (SS1) contains high amounts of all the studied metals except for Fe and Ni compared to Kafr el-Sheikh sludge (SS2). So, metal concentrations in sludge varied depending on several factors such as sludge origin, sludge pretreatment processes, organic matter content, and digestion process [27]. From data in Table 2, it is concluded that trace element concentrations in sewage sludge were relatively low, except for Fe, $\mathrm{Zn}$ and below the permissible upper limits set by EU (which are 2500-4000 for $\mathrm{Zn}, 1000-1750$ for $\mathrm{Cu}, 20-40$ for $\mathrm{Cd}, 750-1200$ for $\mathrm{Pb}$, and $300-400 \mathrm{mg} \mathrm{kg}^{-1}$ for Ni) [26].

3.1.3. Amendments Samples. The $\mathrm{pH}$ of the organic amendments was lower than the inorganic amendments. Coal fly ash (CFA) and sugar beet factory lime (SBFL) recorded the highest $\mathrm{pH}$ values, that is, 12.50 and 12.59 , respectively. Coal fly ash is an alkaline residue produced during the burning of coal for electricity generation usually containing appreciable amounts of ferroaluminum silicate minerals with $\mathrm{Al}, \mathrm{Ca}, \mathrm{Mg}, \mathrm{Fe}, \mathrm{K}, \mathrm{Na}$, and $\mathrm{Si}$ as predominant elements [28]. The alkalinity of FA is depending on its sources and composition [29]. The high alkalinity of the used coal fly ash was reported by $[10,30-32]$. With respect to the high alkalinity of sugar beet factory lime, it may be due to its high content of calcium carbonate (81.6\%, Table 3). Sugar beet factories have traditionally stockpiled factory lime near them which is produced during the sugar beet thin juice purification process. Milk of lime $\left(\mathrm{Ca}(\mathrm{OH})_{2}\right)$ and $\mathrm{CO}_{2}$ are injected into the juice where it forms calcium carbonate and, along with many impurities [33], precipitates from the juice. The purified juice is further processed into crystal sugar, but the precipitated lime and impurities are expelled from the factory and hauled away. This factory lime meets the definition of a liming product and can be used on acidic soils to raise soil $\mathrm{pH}[10]$. Bentonite and $\mathrm{WH}$ showed the highest concentrations of total $\mathrm{Zn}$, while BFA showed the lowest concentrations. Total concentrations of $\mathrm{Cu}$ in the studied amendments were as follows: $60.8,98.6,30.1,4.3$, and $9.7 \mathrm{mg} \mathrm{kg}^{-1}$ for WH, RS, B, CFA, and SBFL, respectively. Bentonite showed the highest total concentration of $\mathrm{Fe}$ (59750 $\mathrm{mg} \mathrm{kg}^{-1}$ ) and $\mathrm{Mn}\left(618.5 \mathrm{mg} \mathrm{kg}^{-1}\right.$ ) compared to all 
TABLE 2: Selected characteristics and metal concentrations in the studied soils and sewage sludge.

\begin{tabular}{|c|c|c|c|c|}
\hline \multirow[b]{2}{*}{ Tested characteristics } & \multicolumn{2}{|c|}{ Soil classification } & \multirow[b]{2}{*}{ Sewage sludge (SS1) } & \multirow[b]{2}{*}{ Sewage sludge (SS2) } \\
\hline & $\begin{array}{c}\text { Calcareous soil } \\
\text { Typic Torrifluvents }\end{array}$ & $\begin{array}{l}\text { Fluvial soil } \\
\text { Typic Calcorthids }\end{array}$ & & \\
\hline \multicolumn{5}{|c|}{ Tested basic characteristics } \\
\hline $\mathrm{pH}$ & 7.82 & 7.71 & 6.28 & 5.86 \\
\hline $\mathrm{EC}, \mathrm{dSm}^{-1}$ & 0.94 & 0.55 & 3.90 & 3.80 \\
\hline $\mathrm{OM}, \mathrm{g} \mathrm{kg}^{-1}$ & 14.90 & 22.20 & 144.50 & 149.20 \\
\hline $\mathrm{CEC}, \mathrm{cmol}(+) / \mathrm{kg}$ & 12.63 & 34.10 & 35.80 & 36.30 \\
\hline $\mathrm{CaCO}_{3}, \%$ & 28.50 & 5.30 & 15.20 & 9.88 \\
\hline Olsen-P, $\mathrm{mg} \mathrm{kg}^{-1}$ & 8.70 & 7.70 & 53.90 & 57.30 \\
\hline \multicolumn{5}{|c|}{ Particle size distribution, $\%$} \\
\hline Sand & 53.58 & 18.52 & - & - \\
\hline Silt & 28.72 & 56.30 & - & - \\
\hline Clay & 17.70 & 25.18 & - & - \\
\hline Texture class & Sandy clay loam & Silty loam & - & - \\
\hline \multicolumn{5}{|c|}{ DTPA-extracted elements, $\mathrm{mg} \mathrm{kg}^{-1}$} \\
\hline $\mathrm{Zn}$ & 2.18 & 1.21 & - & - \\
\hline $\mathrm{Cu}$ & 3.10 & 4.26 & - & - \\
\hline $\mathrm{Pb}$ & 1.25 & 2.18 & - & - \\
\hline $\mathrm{Ni}$ & 0.24 & 0.45 & - & - \\
\hline $\mathrm{Cd}$ & 0.02 & 0.02 & - & - \\
\hline \multicolumn{5}{|c|}{$\begin{array}{l}\text { Aqua-regia-extracted elements, } \\
\mathrm{mg} \mathrm{kg}^{-1}\end{array}$} \\
\hline $\mathrm{Fe}$ & 18250.50 & 55724.00 & 30260.00 & 39907.50 \\
\hline $\mathrm{Mn}$ & 331.50 & 779.00 & 723.00 & 251.00 \\
\hline $\mathrm{Zn}$ & 57.20 & 111.80 & 1437.20 & 1218.10 \\
\hline $\mathrm{Cu}$ & 24.50 & 56.10 & 158.80 & 148.90 \\
\hline $\mathrm{Cd}$ & 1.50 & 1.15 & 1.45 & 1.40 \\
\hline $\mathrm{Ni}$ & 23.10 & 60.00 & 34.10 & 41.90 \\
\hline $\mathrm{Pb}$ & 46.50 & 63.50 & 193.00 & 120.50 \\
\hline
\end{tabular}

EC: electric conductivity $\left(\mathrm{dSm}^{-1}\right)$; OM: organic matter; CEC: cation exchange capacity $(\mathrm{cmol}(+) / \mathrm{kg})$; (-): not measured; DTPA: diethylenetriaminepentaacetic acid.

the studied amendments, while SBFL showed the highest amounts of total $\mathrm{Cd}\left(3.45 \mathrm{mg} \mathrm{kg}^{-1}\right)$ and $\mathrm{Pb}\left(57.0 \mathrm{mg} \mathrm{kg}^{-1}\right)$. On the other hand RS showed the highest amounts of total $\mathrm{Cu}\left(98.6 \mathrm{mg} \mathrm{kg}^{-1}\right)$, CFA showed the highest amounts of $\mathrm{Ni}\left(170.9 \mathrm{mg} \mathrm{kg}^{-1}\right)$, and WH showed the highest amounts of total $\mathrm{Zn}\left(111.4 \mathrm{mg} \mathrm{kg}^{-1}\right)$ compared to all the studied amendments as shown in Table 3 .

3.2. Effect of Sewage Sludge and Stabilized Sewage Sludge Application on P Availability in relation to Soil Type, Sewage Source, Mixing Rate, and Incubation Time. Sewage sludge application increased significantly Olsen-P concentrations from 7.7 to $21.0 \mathrm{mg} \mathrm{kg}^{-1}$ in fluvial soil and from 8.8 to $25.7 \mathrm{mg} \mathrm{kg}^{-1}$ in calcareous soil (Table 4). Moreover, it was observed that Olsen-P concentrations were high in the case of SS2 compared to SS1, in the second incubation period (60 day) compared to the first one (30 day), and in calcareous soil compared to fluvial soil. Also, data in Table 4 showed that mixing the studied amendments with sewage sludge changed relatively the amounts of soilavailable phosphorus. In the second incubation period, stabilized sewage sludge increased significantly available phosphorus compared with the mono-sewage sludge from 20.71 and 21.03 to 23.36 and $22.13 \mathrm{mg} \mathrm{kg}^{-1}$ in fluvial soil with $\mathrm{WH}$ - and $\mathrm{B}$-stabilized $\mathrm{SS}$ at mixing rate $10 \%$, respectively. Also, available $\mathrm{P}$ increased significantly from 25.72 and 24.95 to 28.32 and 27.6 with SBFL-stabilized SS at mixing rate $10 \%$ and $25 \%$, respectively. As indicated from one-way ANOVA (Table 5), there was a significantly difference in $\mathrm{P}$ concentration as affected by soils $(P \leq$ $0.01)$, sewages $(P=0.04)$, incubation periods $(P=$ $0.01)$, or amendments $(P \leq 0.01)$. However, there was insignificant difference in $\mathrm{P}$ concentration as affected by mixing rates $(P=0.05)$. On the other hand, according to a multifactor analysis, the interaction between the studied factors (i.e., soils* sewage sources*incubation periods* mixing rates*amendments) showed a significant difference $(P=$ 0.01 ) in $\mathrm{P}$ concentration (Table 5). 
TABLE 3: Selected characteristics and metal concentrations in the studied amendments.

\begin{tabular}{|c|c|c|c|c|c|c|c|c|}
\hline \multirow{2}{*}{ Properties } & \multicolumn{3}{|c|}{ Organic amendments } & \multicolumn{5}{|c|}{ Inorganic amendments } \\
\hline & WH & RS & CS & BFA & CFA & B & SBFL & $\mathrm{CaCO}_{3}$ \\
\hline $\mathrm{pH}$ & 6.18 & 7.60 & 5.62 & 9.68 & 12.5 & 9.24 & 12.59 & 8.81 \\
\hline $\mathrm{EC}, \mathrm{dSm} \mathrm{m}^{-1}$ & 6.91 & 2.83 & 2.01 & 0.98 & 4.48 & 1.13 & 1.55 & 0.17 \\
\hline OM, \% & 75.25 & 52.7 & 97.49 & - & - & - & - & - \\
\hline $\mathrm{CaCO}_{3}, \%$ & - & - & - & - & 12.4 & - & 81.6 & - \\
\hline \multicolumn{9}{|c|}{ Total elements, $\mathrm{mg} \mathrm{kg}^{-1}$} \\
\hline $\mathrm{Fe}$ & - & - & - & 7590.0 & 21228.0 & 59750.0 & 651.5 & - \\
\hline $\mathrm{Mn}$ & - & - & - & 78.35 & 202.9 & 618.5 & 18.9 & - \\
\hline $\mathrm{Zn}$ & 111.4 & 28.6 & 65.0 & 5.55 & 55.1 & 108.25 & 26.40 & 37.0 \\
\hline $\mathrm{Cu}$ & 60.8 & 98.6 & 47.1 & 4.30 & 30.1 & 33.70 & 9.70 & 41.1 \\
\hline $\mathrm{Cd}$ & nd & nd & nd & nd & 2.15 & 1.35 & 3.45 & nd \\
\hline $\mathrm{Ni}$ & - & - & - & 8.8 & 170.9 & 50.35 & 13.10 & - \\
\hline $\mathrm{Pb}$ & 8.6 & 68.4 & - & 16.0 & 62.5 & 34.5 & 57.00 & - \\
\hline
\end{tabular}

CFA: coal fly ash, B: bentonite, SBFL: sugar beet factory lime, RS: rice straw, WH: water hyacinth, CS: cotton stalks, nd: not detected, —: not measured.

TABLE 4: Effect of SS and stabilized SS on Olsen-P in relation to soil type, sewage source, mixing rate, and incubation period.

\begin{tabular}{|c|c|c|c|c|c|c|c|c|}
\hline \multirow{3}{*}{ Treatments } & \multicolumn{4}{|c|}{ Fluvial soil } & \multicolumn{4}{|c|}{ Calcareous soil } \\
\hline & \multicolumn{2}{|c|}{ SS1 } & \multicolumn{2}{|c|}{ SS2 } & \multicolumn{2}{|c|}{ SS1 } & \multicolumn{2}{|c|}{ SS2 } \\
\hline & 30 day & 60 day & 30 day & 60 day & 30 day & 60 day & 30 day & 60 day \\
\hline \multicolumn{9}{|c|}{ Mixing rate, $10 \%$} \\
\hline $\mathrm{C}$ & $7.7^{\mathrm{f}}$ & $7.7^{\mathrm{d}}$ & $7.7^{\mathrm{e}}$ & $7.6^{c}$ & $8.8^{\mathrm{e}}$ & $8.8^{\mathrm{e}}$ & $8.8^{\mathrm{e}}$ & $8.8^{f}$ \\
\hline SS & $19.4^{\mathrm{c}}$ & $20.7^{\mathrm{b}}$ & $20.7^{b}$ & $21.0^{\mathrm{a}}$ & $25.2^{\mathrm{b}}$ & $25.7^{\mathrm{b}}$ & $24.1^{\mathrm{abc}}$ & $24.9^{c}$ \\
\hline $\mathrm{SS}+\mathrm{CFA}$ & $17.0^{\mathrm{d}}$ & $17.8^{\mathrm{c}}$ & $18.6^{\mathrm{c}}$ & $19.9^{\mathrm{a}}$ & $20.4^{\mathrm{d}}$ & $18.1^{\mathrm{d}}$ & $24.5^{\mathrm{ab}}$ & $27.2^{\mathrm{b}}$ \\
\hline $\mathrm{SS}+\mathrm{B}$ & $21.8^{\mathrm{a}}$ & $18.0^{c}$ & $23.6^{\mathrm{a}}$ & $22.1^{\mathrm{a}}$ & $22.1^{\mathrm{c}}$ & $25.2^{\mathrm{b}}$ & $26.1^{\mathrm{a}}$ & $25.9^{c}$ \\
\hline $\mathrm{SS}+\mathrm{SBFL}$ & $21.2^{\mathrm{ab}}$ & $19.3^{b c}$ & $21.2^{\mathrm{b}}$ & $20.8^{\mathrm{a}}$ & $31.3^{\mathrm{a}}$ & $28.3^{\mathrm{a}}$ & $21.9^{\mathrm{bcd}}$ & $29.2^{\mathrm{a}}$ \\
\hline $\mathrm{SS}+\mathrm{CaCO}_{3}$ & $20.0^{\mathrm{bc}}$ & $18.7^{\mathrm{bc}}$ & $17.3^{\mathrm{cd}}$ & $15.3^{\mathrm{b}}$ & $26.1^{\mathrm{b}}$ & $27.3^{\mathrm{ab}}$ & $22.8^{\mathrm{abcd}}$ & $21.3^{\mathrm{d}}$ \\
\hline $\mathrm{SS}+\mathrm{WH}$ & $18.8^{\mathrm{c}}$ & $23.4^{\mathrm{a}}$ & $16.9^{\mathrm{cd}}$ & $15.5^{\mathrm{b}}$ & $20.7^{\mathrm{d}}$ & $22.5^{c}$ & $20.7^{\mathrm{cd}}$ & $21.6^{\mathrm{d}}$ \\
\hline $\mathrm{SS}+\mathrm{RS}$ & $15.2^{\mathrm{e}}$ & $17.6^{\mathrm{c}}$ & $15.6^{\mathrm{d}}$ & $20.7^{\mathrm{a}}$ & $21.0^{\mathrm{cd}}$ & $20.0^{\mathrm{cd}}$ & $21.0^{\mathrm{bcd}}$ & $19.3^{\mathrm{e}}$ \\
\hline $\mathrm{SS}+\mathrm{CS}$ & $16.9^{\mathrm{d}}$ & $18.7^{\mathrm{bc}}$ & $16.1^{\mathrm{d}}$ & $19.1^{\mathrm{ab}}$ & $19.9^{\mathrm{d}}$ & $20.2^{\mathrm{cd}}$ & $19.8^{\mathrm{d}}$ & $22.3^{\mathrm{d}}$ \\
\hline \multicolumn{9}{|c|}{ Mixing rate, $25 \%$} \\
\hline $\mathrm{C}$ & $7.7^{\mathrm{c}}$ & $7.6^{\mathrm{f}}$ & $7.7^{\mathrm{f}}$ & $7.6^{\mathrm{d}}$ & $8.8^{\mathrm{h}}$ & $8.8^{\mathrm{e}}$ & $8.8^{\mathrm{f}}$ & $8.8^{\mathrm{f}}$ \\
\hline SS & $19.4^{\mathrm{a}}$ & $20.7^{\mathrm{ab}}$ & $20.7^{b}$ & $21.0^{\mathrm{a}}$ & $25.2^{\mathrm{b}}$ & $25.7^{\mathrm{a}}$ & $24.1^{\mathrm{b}}$ & $24.9^{c}$ \\
\hline $\mathrm{SS}+\mathrm{CFA}$ & $16.6^{\mathrm{b}}$ & $16.3^{\mathrm{de}}$ & $19.8^{\mathrm{bc}}$ & $21.8^{\mathrm{a}}$ & $19.9^{\mathrm{ef}}$ & $20.9^{b c}$ & $22.5^{\mathrm{bc}}$ & $25.4^{\mathrm{bc}}$ \\
\hline $\mathrm{SS}+\mathrm{B}$ & $21.2^{\mathrm{a}}$ & $18.6^{\mathrm{abcd}}$ & $23.3^{\mathrm{a}}$ & $21.2^{\mathrm{a}}$ & $21.8^{\mathrm{de}}$ & $22.6^{\mathrm{b}}$ & $24.5^{\mathrm{b}}$ & $29.7^{\mathrm{a}}$ \\
\hline $\mathrm{SS}+\mathrm{SBFL}$ & $19.7^{\mathrm{a}}$ & $21.0^{\mathrm{a}}$ & $18.2^{\mathrm{cd}}$ & $20.7^{\mathrm{a}}$ & $27.9^{\mathrm{a}}$ & $26.6^{\mathrm{a}}$ & $28.0^{\mathrm{a}}$ & $27.6^{\mathrm{ab}}$ \\
\hline $\mathrm{SS}+\mathrm{CaCO}_{3}$ & $16.9^{\mathrm{b}}$ & $18.1^{\mathrm{bcd}}$ & $17.0^{\mathrm{de}}$ & $16.9^{c}$ & $24.3^{\mathrm{bc}}$ & $25.8^{\mathrm{a}}$ & $21.8^{\mathrm{cd}}$ & $21.6^{\mathrm{d}}$ \\
\hline $\mathrm{SS}+\mathrm{WH}$ & $19.4^{\mathrm{a}}$ & $17.8^{\text {cde }}$ & $16.3^{\mathrm{e}}$ & $16.5^{\mathrm{c}}$ & $18.5^{\mathrm{fg}}$ & $20.4^{\mathrm{c}}$ & $19.8^{\mathrm{de}}$ & $21.9^{d}$ \\
\hline $\mathrm{SS}+\mathrm{RS}$ & $14.8^{\mathrm{b}}$ & $15.3^{\mathrm{e}}$ & $16.2^{\mathrm{e}}$ & $16.9^{c}$ & $18.1^{\mathrm{g}}$ & $17.4^{\mathrm{d}}$ & $18.8^{\mathrm{e}}$ & $19.1^{\mathrm{e}}$ \\
\hline $\mathrm{SS}+\mathrm{CS}$ & $19.5^{\mathrm{a}}$ & $19.3^{\mathrm{abc}}$ & $19.5^{\mathrm{bc}}$ & $19.1^{b}$ & $22.7^{\mathrm{cd}}$ & $21.3^{\mathrm{bc}}$ & $22.6^{\mathrm{bc}}$ & $21.9^{d}$ \\
\hline
\end{tabular}

Values accompanied by different letters are significantly different within column $(P<0.05)$.

C: control (un amended soil), SS: sewage sludge, CFA: coal fly ash, B: bentonite, SBFL: sugar beet factory lime, RS: rice straw, WH: water hyacinth, CS: cotton stalks, nd: not detected, —: not measured.

Our results were in consistency with [34] who reported that some amendments-stabilized sewage sludge increased significantly available phosphorus. The highest increase in available $\mathrm{P}$ was found in the treatment SBFL $\left(29.68 \mathrm{mg} \mathrm{kg}^{-1}\right)$. This increase in available $\mathrm{P}$ because of the lime application may be attributed to the decomposition of organic $\mathrm{P}$ as it was stated by [35]. Also, this is probably due to the high available $\mathrm{P}$ content of this amendment $\left(391 \mathrm{mg} \mathrm{kg}^{-1}\right)$ [10]. The enrichment of SBFL in P could be due to its formation process. Also, it may be due to the increase of exchangeable Ca in lime treatment which increases the calcium phosphate. In this respect, $[8,36]$ reported that the increase in Olsen-P for treatments receiving alkaline materials compared to the control was likely related to an increase in Ca-associated $\mathrm{P}$ which is extractable with $0.5 \mathrm{M} \mathrm{NaHCO}_{3}$. Also, [37] studied the crop availability of SBFL phosphorus and found that Olsen-P was increased with the application of factory lime. Additionally, the increased Olsen-P response to factory lime 
TABLE 5: Multifactor analysis of statistical differences in $\mathrm{P}, \mathrm{Cu}$, and $\mathrm{Zn}$ concentrations as affected by soil types, sewage source, mixing rate, and incubation time.

\begin{tabular}{cccccccc}
\hline & Source & Soils & Sewages & Rates & Incubation periods & Amendments & $\begin{array}{c}\text { Soils* sewages* rates*incubation } \\
\text { periods*amendments }\end{array}$ \\
\hline \multirow{2}{*}{$\mathrm{P}$} & $\mathrm{DF}$ & 1 & 1 & 1 & 1 & 8 & 8 \\
& $F$ ratio & 949.08 & 8.23 & 3.79 & 10.37 & 620.57 & 3.39 \\
& Prob $>F$ & $<0.01^{*}$ & $0.04^{*}$ & 0.05 & $0.01^{*}$ & $<0.01^{*}$ & $0.01^{*}$ \\
$\mathrm{Zn}$ & $\mathrm{DF}$ & 1 & 1 & 1 & 1 & 8 & 8 \\
& $F$ ratio & 278.49 & 90.99 & 3.49 & 216.33 & 894.80 & 1.15 \\
& Prob $>F$ & $<0.01^{*}$ & $<0.01^{*}$ & 0.06 & $<0.01^{*}$ & $<0.01^{*}$ & 0.32 \\
$\mathrm{Cu}$ & DF & 1 & 1 & 1 & 1 & 8 & 8 \\
& $F$ ratio & 1.23 & 1.01 & 1.01 & 0.96 & 0.99 & 0.99 \\
\end{tabular}

rates was probably due to increased solubilization of factory lime $\mathrm{P}$ as the factory lime reacted with the soil over the time [37].

\subsection{Effect of Sewage Sludge and Stabilized Sewage Sludge Application on DTPA-Extractable $Z n$ in relation to Soil Type, Sewage Source, Mixing Rate, and Incubation Time}

3.3.1. Effect of Mono Sewage Sludge Treatment on DTPAExtractable $\mathrm{Zn}$. The application of SS increased significantly DTPA extractable $\mathrm{Zn}$ compared to untreated soil from 1.20 to $9.57 \mathrm{mg} \mathrm{kg}^{-1}$ with increasing percent $684 \%$ and from 2.16 to $10.50 \mathrm{mg} \mathrm{kg}^{-1}$ with increasing percent $367 \%$ in fluvial and calcareous soil, respectively. This increase could be explained by the following possible reasons: high content of $\mathrm{Zn}$ in sewage sludge (1437 $\mathrm{mg} \mathrm{kg}^{-1}$, Table 2); formation of soluble $\mathrm{Zn}$-organic associations and the decrease in soil pH. These interpretations are in agreement with [38]. In this respect, [1, 39] reported that SSs exhibit a wide range of $\mathrm{Zn}$ concentrations which are generally higher than the background levels found in soils. Increasing of DTPA extractable $\mathrm{Zn}$ after biosolid application seems to agree with those reported in an early study by $[12,13,15,31]$.

Also, data indicated that the increasing rate was high with SS2 compared to SS1 in fluvial soil especially after the first incubation period. However, the opposite trend was recorded in calcareous soil, where SS1 application increased available $\mathrm{Zn}$ compared to SS2 especially in the first incubation period. Additionally, fluvial soil showed increasing rate higher than calcareous soil. Lower increase rate of DTPA-extractable $\mathrm{Zn}$ in calcareous soil compared to fluvial one after application of SS may be due to the precipitation and/or sorption of biosolid-born released $\mathrm{Zn}$ with calcium carbonate. Increasing $\mathrm{Zn}$ sorption in soils rich in $\mathrm{CaCO}_{3}$ may be due to the formation of $\mathrm{ZnCO}_{3}$ and/or $\mathrm{Zn}$ sorption by calcium and magnesium carbonate. In this respect, [40] reported that $\mathrm{Zn}$ can be strongly sorbed by magnesite $\left(\mathrm{MgCO}_{3}\right)$, to intermediate degree by dolomite $\left[\mathrm{Ca} \mathrm{Mg}\left(\mathrm{CO}_{3}\right)\right]$ and latest by calcite $\mathrm{CaCO}_{3}$. In magnesite and dolomite, it appears that $\mathrm{Zn}$ is actually adsorbed into the crystal surface at the sites in lattice normally occupied by magnesium atoms. Also, in the presence of $\mathrm{Ca}^{+2}$, a more or less fraction of $\mathrm{Zn}$ may be involved in specific adsorption reactions. Kiekens [40] studied the reversibility of the exchange reaction between soil $\mathrm{Ca}^{+2}$ and solution $\mathrm{Zn}$ and found that an important fraction of $\mathrm{Zn}$ was irreversible fixed by the soil. Additionally, under the high $\mathrm{pH}$ values of these alkaline soils, the increasing of $\mathrm{Zn}$ sorption could be explained by the adsorption of $\mathrm{Zn}$ in hydrolysed form and precipitation of $\mathrm{Zn}\left(\mathrm{OH}_{2}\right)$. Similar results and interpretations about the high affinity of calcareous soil for $\mathrm{Zn}$ sorption were reported by [13].

3.3.2. Effect of Stabilized Sewage Sludge Treatment on DTPAExtractable $\mathrm{Zn}$. The data showed that mixing SS with the studied amendments decreased significantly the amounts of DTPA-extractable $\mathrm{Zn}$ in both fluvial and calcareous soil with SS1 and SS2 and after both mixing rates and incubation periods except for CS-stabilized SS in some cases (Table 6). However, the decreasing rate differed depending on type of amendments, soils, mixing rate, incubation period, and SS source.

Regarding the efficacy of tested amendments in reducing the $\mathrm{Zn}$ availability in biosolid amended soil, they differed widely depending on soil type and sewage source. In fluvial soil, in the case of SS1 and mixing rate 25\% after 60day incubation period, B- and CFA-stabilized SS treatment showed the highest decreasing rate of available $\mathrm{Zn}$ compared to the mono-SS treatment between the inorganic amendments and RS-stabilized SS between the organic ones. On the other hand, in calcareous soil and in the case of SS1 and mixing rate $25 \%$ after 60 -day incubation period, B-stabilized SS treatment showed the highest decreasing percent of available $\mathrm{Zn}$ compared to the mono-SS treatment $(9.6 \%$ reduction), while $\mathrm{WH}$-stabilized SS treatment showed the highest decreasing percent between the organic amendments (35.2\% reduction). These trends indicate that $\mathrm{B}$ was the best inorganic amendment for reducing DTPA-extractable Zn either in fluvial or calcareous soil. This result indicates that $\mathrm{B}$ has the ability to take up a significant concentration of $\mathrm{Zn}$ associated with the mobile forms. The fact that the bentonite binds the available element form had been reported before by [41]. 
TABLE 6: Effect of sewage sludge and stabilized sewage sludge on the DTPA-extractable zinc in relation to soil type, sewage source, mixing rate, and incubation period.

\begin{tabular}{|c|c|c|c|c|c|c|c|c|}
\hline \multirow{3}{*}{ Treatments } & \multicolumn{4}{|c|}{ Fluvial soil } & \multicolumn{4}{|c|}{ Calcareous soil } \\
\hline & \multicolumn{2}{|c|}{ SS1 } & \multicolumn{2}{|c|}{ SS2 } & \multicolumn{2}{|c|}{ SS1 } & \multicolumn{2}{|c|}{ SS2 } \\
\hline & 30 day & 60 day & 30 day & 60 day & 30 day & 60 day & 30 day & 60 day \\
\hline \multicolumn{9}{|c|}{ Mixing rate, $10 \%$} \\
\hline $\mathrm{C}$ & $1.21^{\mathrm{f}}$ & $1.20^{\mathrm{e}}$ & $1.21^{\mathrm{d}}$ & $1.20^{\mathrm{e}}$ & $2.18^{\mathrm{e}}$ & $2.16^{\mathrm{e}}$ & $2.18^{\mathrm{f}}$ & $2.16^{\mathrm{e}}$ \\
\hline SS & $8.46^{\mathrm{ab}}$ & $8.11^{\mathrm{a}}$ & $9.57^{\mathrm{a}}$ & $7.80^{\mathrm{b}}$ & $10.50^{\mathrm{a}}$ & $8.84^{\mathrm{a}}$ & $10.10^{\mathrm{a}}$ & $9.15^{\mathrm{a}}$ \\
\hline $\mathrm{SS}+\mathrm{CFA}$ & $7.77^{\mathrm{bcd}}$ & $6.40^{\mathrm{c}}$ & $7.46^{\mathrm{bc}}$ & $6.39^{\mathrm{cd}}$ & $9.02^{\mathrm{b}}$ & $6.51^{\mathrm{cd}}$ & $9.46^{\mathrm{bc}}$ & $7.79^{\mathrm{b}}$ \\
\hline $\mathrm{SS}+\mathrm{B}$ & $7.49^{\text {cde }}$ & $7.36^{\mathrm{ab}}$ & $7.56^{\mathrm{bc}}$ & $7.46^{\mathrm{b}}$ & $6.24^{\mathrm{a}}$ & $7.13^{\mathrm{bc}}$ & $8.63^{d}$ & $7.60^{\mathrm{bc}}$ \\
\hline $\mathrm{SS}+\mathrm{SBFL}$ & $8.15^{\mathrm{abc}}$ & $6.49^{c}$ & $7.59^{\mathrm{bc}}$ & $6.68^{\mathrm{cd}}$ & $7.57^{\mathrm{c}}$ & $8.10^{\mathrm{a}}$ & $8.78^{\mathrm{d}}$ & $7.81^{\mathrm{b}}$ \\
\hline $\mathrm{SS}+\mathrm{CaCO}_{3}$ & $7.19^{\mathrm{de}}$ & $6.63^{\mathrm{bc}}$ & $7.57^{\mathrm{bc}}$ & $6.85^{\mathrm{c}}$ & $7.76^{\mathrm{c}}$ & $7.32^{\mathrm{b}}$ & $8.89^{\mathrm{cd}}$ & $6.72^{\mathrm{cd}}$ \\
\hline $\mathrm{SS}+\mathrm{WH}$ & $7.15^{\mathrm{de}}$ & $6.18^{\mathrm{c}}$ & $7.37^{\mathrm{c}}$ & $6.07^{\mathrm{d}}$ & $7.22^{\mathrm{c}}$ & $6.69^{\mathrm{bcd}}$ & $6.87^{\mathrm{e}}$ & $6.49^{\mathrm{d}}$ \\
\hline $\mathrm{SS}+\mathrm{RS}$ & $6.78^{\mathrm{e}}$ & $5.35^{\mathrm{d}}$ & $8.14^{\mathrm{b}}$ & $7.72^{\mathrm{b}}$ & $7.54^{\mathrm{c}}$ & $6.01^{\mathrm{d}}$ & $9.04^{\mathrm{bcd}}$ & $7.96^{\mathrm{b}}$ \\
\hline $\mathrm{SS}+\mathrm{CS}$ & $8.89^{\mathrm{a}}$ & $7.33^{\mathrm{ab}}$ & $7.85^{\mathrm{bc}}$ & $8.60^{\mathrm{a}}$ & $8.62^{\mathrm{b}}$ & $8.19^{\mathrm{a}}$ & $9.66^{\mathrm{ab}}$ & $9.70^{\mathrm{a}}$ \\
\hline \multicolumn{9}{|c|}{ Mixing rate, $25 \%$} \\
\hline $\mathrm{C}$ & $1.21^{\mathrm{c}}$ & $1.20^{\mathrm{e}}$ & $1.21^{\mathrm{e}}$ & $1.20^{\mathrm{f}}$ & $2.18^{\mathrm{e}}$ & $2.16^{\mathrm{f}}$ & $2.18^{\mathrm{d}}$ & $2.16^{\mathrm{g}}$ \\
\hline SS & $8.46^{\mathrm{a}}$ & $8.11^{\mathrm{a}}$ & $9.57^{\mathrm{a}}$ & $7.80^{\mathrm{a}}$ & $10.5^{\mathrm{a}}$ & $8.84^{\mathrm{b}}$ & $10.10^{\mathrm{a}}$ & $9.15^{\mathrm{a}}$ \\
\hline $\mathrm{SS}+\mathrm{CFA}$ & $7.24^{\mathrm{ab}}$ & $5.77^{\mathrm{cd}}$ & $7.50^{\mathrm{bc}}$ & $7.14^{\mathrm{bc}}$ & $8.36^{\mathrm{bc}}$ & $7.24^{\mathrm{d}}$ & $7.92^{\mathrm{bc}}$ & $7.39^{\mathrm{de}}$ \\
\hline$S S+B$ & $6.86^{\mathrm{ab}}$ & $5.64^{\mathrm{cd}}$ & $7.28^{c}$ & $7.31^{\mathrm{b}}$ & $7.72^{\mathrm{bcd}}$ & $7.99^{c}$ & $8.75^{\mathrm{b}}$ & $7.87^{\mathrm{bcd}}$ \\
\hline $\mathrm{SS}+\mathrm{SBFL}$ & $7.33^{\mathrm{ab}}$ & $6.70^{\mathrm{b}}$ & $8.00^{\mathrm{b}}$ & $7.34^{\mathrm{b}}$ & $7.12^{\mathrm{cd}}$ & $8.22^{c}$ & $7.98^{\mathrm{bc}}$ & $7.54^{\text {cde }}$ \\
\hline $\mathrm{SS}+\mathrm{CaCO}_{3}$ & $6.12^{\mathrm{b}}$ & $8.00^{\mathrm{a}}$ & $7.37^{\mathrm{bc}}$ & $6.28^{\mathrm{d}}$ & $8.17^{\mathrm{bc}}$ & $7.34^{\mathrm{d}}$ & $8.64^{\mathrm{b}}$ & $6.00^{\mathrm{f}}$ \\
\hline $\mathrm{SS}+\mathrm{WH}$ & $6.66^{\mathrm{b}}$ & $6.29^{\mathrm{bc}}$ & $5.99^{d}$ & $5.80^{\mathrm{e}}$ & $6.52^{\mathrm{d}}$ & $5.73^{\mathrm{e}}$ & $7.20^{\mathrm{c}}$ & $6.90^{\mathrm{e}}$ \\
\hline $\mathrm{SS}+\mathrm{RS}$ & $6.66^{\mathrm{b}}$ & $4.83^{\mathrm{d}}$ & $9.17^{\mathrm{a}}$ & $7.49^{\mathrm{ab}}$ & $7.17^{\mathrm{cd}}$ & $6.25^{\mathrm{e}}$ & $9.74^{\mathrm{a}}$ & $8.33^{\mathrm{abc}}$ \\
\hline $\mathrm{SS}+\mathrm{CS}$ & $7.56^{\mathrm{ab}}$ & $7.88^{\mathrm{a}}$ & $8.92^{\mathrm{a}}$ & $6.88^{c}$ & $8.71^{\mathrm{b}}$ & $9.64^{\mathrm{a}}$ & $9.95^{\mathrm{a}}$ & $8.73^{\mathrm{ab}}$ \\
\hline
\end{tabular}

Values accompanied by different letters are significantly different within column $(P<0.05)$.

One-way ANOVA showed a significant difference in $\mathrm{Zn}$ concentration as affected by sewage, soils, sewages, incubation periods, or amendments at the same significance level in each one of them $(P \leq 0.01)$, whereas there was insignificant difference in $\mathrm{Zn}$ concentration in case of rates $(P=0.06)$. In addition, a multifactor analysis was performed to evaluate significant statistically differences in $\mathrm{Zn}$ concentration as affected by soils*sewage sources*mixing rates*incubation periods*amendments. There was insignificant difference in $\mathrm{Zn}$ concentration $(P=0.32)$ at interference between these factors as presented in Table 5 .

The efficiency of CFA in reducing the availability of $\mathrm{Zn}$ in biosolid-amended soils may be due to its high alkalinity $(\mathrm{pH}=12.5$ Table 3$)$ and its high ability to adsorb the released biosolid-born Zn. The high ability of CFA in sorption of $\mathrm{Zn}$ in biosolid-amended soil was studied by Tsadilas et al. [30] who reported that application of CFA increased sorption of $\mathrm{Zn}$ about 10 times greater than the control. In addition, Ciccu et al. [42] stated that FA may increase the surface area available for element adsorption, increase $\mathrm{pH}$ of soils, and render most cationic metals less mobile. Also, Tsadilas et al. [43] studied the influence of FA and sewage sludge application on the bioavailability of $\mathrm{Zn}$ and showed that fly ash application did not affect total concentration of soil $\mathrm{Zn}$ but decreased significantly their available forms in all cases from about 32 to $73 \%$ compared to the control treatment.
These results confirmed that alkaline fly ash can be used as an effective amendment for remediation of sewage sludgeamended soils.

Also, data in Table 6 showed that WH-stabilized SS was the best organic amendment in reducing DTPA-extractable $\mathrm{Zn}$ compared with other amendments. The high efficiency of $\mathrm{WH}$ in decreasing $\mathrm{Zn}$ availability was in agreement with $[44,45]$. The increasing of available $\mathrm{Zn}$ in CS-stabilized SS treatment compared to the mono-SS treatment could be explained by its low $\mathrm{pH}(\mathrm{pH}=5.62$, Table 3$)$.

The results indicated that the decreasing rate of available $\mathrm{Zn}$ in stabilized SS treatments increased with increasing the mixing rate from 10 to $25 \%$ and with increasing the incubation period from 30 to 60 days. The $25 \%$ application rate was the best rate in reducing DTPA-extractable $\mathrm{Zn}$ either in the first or in the second incubation period. Also, data showed that the DTPA-extractable Zn decreased over incubation time. This result was in accordance with [46]. Also [47] reported that solution $\mathrm{Zn}$ concentrations slightly decreased during the incubation study after mixing FA with SS and achieved the stable level after 22 days.

In regards to the effect of soil types, results indicated that the fluvial showed the best response for the effect of the tested amendments in decreasing DTPA-extractable Zn compared to calcareous soil in both incubation periods. The differences between the studied soils were highly significant. With 
TABLE 7: Effect of sewage sludge and stabilized sewage sludge on the DTPA-extractable copper in relation to soil type, sewage source, mixing rate, and incubation period.

\begin{tabular}{|c|c|c|c|c|c|c|c|c|}
\hline \multirow{3}{*}{ Treatments } & \multicolumn{4}{|c|}{ Fluvial soil } & \multicolumn{4}{|c|}{ Calcareous soil } \\
\hline & \multicolumn{2}{|c|}{ SS1 } & \multicolumn{2}{|c|}{ SS2 } & \multicolumn{2}{|c|}{ SS1 } & \multicolumn{2}{|c|}{ SS2 } \\
\hline & 30 day & 60 day & 30 day & 60 day & 30 day & 60 day & 30 day & 60 day \\
\hline \multicolumn{9}{|c|}{ Mixing rate, $10 \%$} \\
\hline $\mathrm{C}$ & $3.86^{\mathrm{d}}$ & $3.88^{\mathrm{d}}$ & $3.86^{\mathrm{d}}$ & $3.88^{\mathrm{b}}$ & $3.11^{\mathrm{d}}$ & $3.10^{\mathrm{d}}$ & $3.11^{\mathrm{b}}$ & $3.10^{\mathrm{a}}$ \\
\hline SS & $7.01^{\mathrm{a}}$ & $6.98^{\mathrm{a}}$ & $6.95^{\mathrm{a}}$ & $6.90^{\mathrm{a}}$ & $6.17^{\mathrm{a}}$ & $4.68^{\mathrm{a}}$ & $4.39^{\mathrm{a}}$ & $3.64^{\mathrm{a}}$ \\
\hline $\mathrm{SS}+\mathrm{CFA}$ & $6.70^{\mathrm{a}}$ & $6.03^{\mathrm{b}}$ & $6.62^{\mathrm{ab}}$ & $6.62^{\mathrm{a}}$ & $4.11^{\mathrm{c}}$ & $3.19^{\mathrm{d}}$ & $3.39^{\mathrm{b}}$ & $3.29^{\mathrm{a}}$ \\
\hline $\mathrm{SS}+\mathrm{B}$ & $6.22^{\mathrm{b}}$ & $6.85^{\mathrm{a}}$ & $6.21^{\mathrm{bc}}$ & $5.98^{\mathrm{a}}$ & $2.88^{\mathrm{e}}$ & $3.57^{\mathrm{cd}}$ & $3.36^{\mathrm{b}}$ & $2.77^{\mathrm{a}}$ \\
\hline $\mathrm{SS}+\mathrm{SBFL}$ & $6.40^{\mathrm{ab}}$ & $6.80^{\mathrm{a}}$ & $6.90^{\mathrm{ab}}$ & $6.55^{\mathrm{a}}$ & $3.66^{c}$ & $3.88^{\mathrm{bc}}$ & $4.25^{\mathrm{a}}$ & $3.62^{\mathrm{a}}$ \\
\hline $\mathrm{SS}+\mathrm{CaCO}_{3}$ & $6.99^{\mathrm{a}}$ & $6.94^{\mathrm{a}}$ & $6.80^{\mathrm{ab}}$ & $6.30^{\mathrm{a}}$ & $3.96^{\mathrm{c}}$ & $4.35^{\mathrm{ab}}$ & $4.32^{\mathrm{a}}$ & $3.36^{\mathrm{a}}$ \\
\hline $\mathrm{SS}+\mathrm{WH}$ & $6.73^{\mathrm{a}}$ & $5.79^{\mathrm{b}}$ & $5.88^{c}$ & $4.20^{\mathrm{b}}$ & $3.81^{\mathrm{c}}$ & $3.33^{\mathrm{d}}$ & $3.12^{\mathrm{b}}$ & $3.18^{\mathrm{a}}$ \\
\hline $\mathrm{SS}+\mathrm{RS}$ & $5.27^{\mathrm{c}}$ & $4.63^{c}$ & $6.55^{\mathrm{ab}}$ & $6.89^{\mathrm{a}}$ & $3.89^{c}$ & $3.36^{\mathrm{d}}$ & $4.34^{\mathrm{a}}$ & $3.55^{\mathrm{a}}$ \\
\hline $\mathrm{SS}+\mathrm{CS}$ & $6.69^{\mathrm{a}}$ & $6.95^{\mathrm{a}}$ & $6.71^{\mathrm{ab}}$ & $5.97^{\mathrm{a}}$ & $4.87^{\mathrm{b}}$ & $3.33^{\mathrm{d}}$ & $4.12^{\mathrm{a}}$ & $3.39^{\mathrm{a}}$ \\
\hline \multicolumn{9}{|c|}{ Mixing rate, $25 \%$} \\
\hline $\mathrm{C}$ & $3.86^{c}$ & $3.88^{\mathrm{e}}$ & $3.86^{\mathrm{d}}$ & $3.88^{\mathrm{e}}$ & $3.11^{\mathrm{d}}$ & $3.10^{\mathrm{cd}}$ & $3.11^{\mathrm{c}}$ & $3.10^{\mathrm{bc}}$ \\
\hline SS & $7.01^{\mathrm{ab}}$ & $6.98^{\mathrm{a}}$ & $6.95^{\mathrm{ab}}$ & $6.90^{\mathrm{a}}$ & $6.17^{a}$ & $4.68^{\mathrm{a}}$ & $4.39^{\mathrm{a}}$ & $3.64^{\mathrm{a}}$ \\
\hline $\mathrm{SS}+\mathrm{CFA}$ & $6.46^{\mathrm{ab}}$ & $5.18^{\mathrm{cd}}$ & $5.92^{c}$ & $5.53^{\mathrm{b}}$ & $3.26^{\mathrm{d}}$ & $2.88^{\mathrm{d}}$ & $2.63^{\mathrm{d}}$ & $2.97^{\mathrm{cd}}$ \\
\hline$S S+B$ & $5.80^{\mathrm{ab}}$ & $5.59^{\mathrm{bcd}}$ & $5.72^{\mathrm{c}}$ & $5.25^{\mathrm{bc}}$ & $3.27^{\mathrm{d}}$ & $3.39^{\mathrm{bc}}$ & $3.88^{\mathrm{b}}$ & $2.62^{\mathrm{d}}$ \\
\hline $\mathrm{SS}+\mathrm{SBFL}$ & $6.37^{\mathrm{ab}}$ & $6.50^{\mathrm{ab}}$ & $6.89^{\mathrm{ab}}$ & $6.59^{\mathrm{a}}$ & $3.52^{\mathrm{cd}}$ & $3.60^{\mathrm{b}}$ & $3.78^{\mathrm{b}}$ & $3.50^{\mathrm{a}}$ \\
\hline $\mathrm{SS}+\mathrm{CaCO}_{3}$ & $7.21^{\mathrm{a}}$ & $7.11^{\mathrm{a}}$ & $7.28^{\mathrm{a}}$ & $6.77^{\mathrm{a}}$ & $4.05^{\mathrm{bc}}$ & $4.59^{\mathrm{a}}$ & $4.47^{\mathrm{a}}$ & $3.44^{\mathrm{ab}}$ \\
\hline $\mathrm{SS}+\mathrm{WH}$ & $6.40^{\mathrm{ab}}$ & $5.98^{\mathrm{abc}}$ & $6.00^{\mathrm{bc}}$ & $4.02^{\mathrm{de}}$ & $3.54^{\text {cd }}$ & $2.81^{\mathrm{d}}$ & $2.75^{\mathrm{cd}}$ & $2.99^{\mathrm{cd}}$ \\
\hline $\mathrm{SS}+\mathrm{RS}$ & $5.22^{\mathrm{bc}}$ & $4.59^{\mathrm{de}}$ & $6.51^{\mathrm{abc}}$ & $6.64^{\mathrm{a}}$ & $3.67^{\mathrm{bcd}}$ & $2.70^{\mathrm{d}}$ & $3.85^{\mathrm{b}}$ & $2.74^{\mathrm{cd}}$ \\
\hline $\mathrm{SS}+\mathrm{CS}$ & $6.31^{\mathrm{ab}}$ & $6.39^{\mathrm{ab}}$ & $6.12^{\mathrm{bc}}$ & $4.73^{\mathrm{cd}}$ & $4.32^{\mathrm{b}}$ & $3.67^{\mathrm{b}}$ & $4.19^{\mathrm{ab}}$ & $2.84^{\mathrm{cd}}$ \\
\hline
\end{tabular}

Values accompanied by different letters are significantly different within column $(P<0.05)$.

respect to sewage sources, SS1 showed a positive significance response for all the studied amendments in reducing DTPAZn compared to SS2.

\subsection{Effect of Sewage Sludge and Stabilized Sewage Sludge Application on DTPA-Extractable Copper in relation to Soil Type, Sewage Source, Mixing Rate, and Incubation Time}

3.4.1. Effect of Sewage Sludge Treatment on DTPA-Extractable Copper. In fluvial soil the DTPA-extractable $\mathrm{Cu}$ increased from 3.86 to 7.01 and $6.95 \mathrm{mg} \mathrm{kg}^{-1}$ with SS1 and SS2, respectively. In calcareous soil, the DTPA-extractable $\mathrm{Cu}$ increased from 3.10 to 6.17 and $4.39 \mathrm{mg} \mathrm{kg}^{-1}$ with SS1 and SS2, respectively (Table 7). Enrichment of soil by $\mathrm{Cu}$ as a result of SS application could be explained by its relatively high concentration of total $\mathrm{Cu}\left(158.8 \mathrm{mg} \mathrm{kg}^{-1}\right.$, Table 2). This is in consistent with [1] who found that $\mathrm{Cu}$ concentration in soil increased in soil amended with sewage sludge as compared to unamended control soil. Also, these results were in agreement with [48] who noticed that at the end of incubation period (60 days), following biosolids application, DTPA-extractable $\mathrm{Cu}$ increased with increasing biosolids application.

Also, data indicated that the increasing rate of DTPAextractable $\mathrm{Cu}$ was high with SS1 compared to SS2 either in fluvial or calcareous soil. Additionally, fluvial soil showed increasing rate higher than calcareous soil. Decreasing rate of DTPA-extractable $\mathrm{Cu}$ in calcareous soil compared to fluvial one after application of SS may be due to the precipitation and/or sorption of biosolid-born released $\mathrm{Cu}$ with calcium carbonate. In this respect, [49] studied sorption of copper in different soils of Egypt and reported that $\mathrm{Cu}$ adsorption by the Egyptian Aridisol may be attributed to the presence of high amounts of total calcium carbonate in this soil compared to the clayey fluvial soils. This interpretation is in agreement with [50] who reported that calcareous soils may retain higher amounts of $\mathrm{Cu}$ than acidic and neutral soils because of the greater adsorption of $\mathrm{Cu}$ on $\mathrm{CaCO}_{3}$ particles.

\subsubsection{Effect of Stabilized Sewage Sludge Treatment on DTPA-} Extractable Copper. Mixing SS with the studied amendments changed significantly the amounts of DTPA-extractable $\mathrm{Cu}$ depending on type of amendments, soils, mixing rate, incubation period, and SS source (Table 7). There was insignificant difference in $\mathrm{Cu}$ concentration when affected by any of the studied factors (i.e., soils $(P=0.26)$, sewages $(P=0.31)$, rates $(P=0.31)$, incubation periods $(P=0.32)$, or amendments $(P=0.34)$ (Table 5$)$.

Regarding the efficacy of tested amendments in reducing the $\mathrm{Cu}$ availability in biosolid-amended soil, they differed widely depending on soil type and sewage source. In fluvial soil, in the case of SS1, B-, SBFL-, and CFA-stabilized SS treatment showed the highest significant decreasing rate of available $\mathrm{Cu}$ compared to the mono-SS treatment between 
the inorganic amendments and RS- and WH-stabilized SS between the organic ones. On the other hand, in calcareous soil, and also in the case of SS1, B, SBFL-, and CFA-stabilized SS treatment showed the highest significant decreasing rate of available $\mathrm{Cu}$ compared to the mono-SS treatment, while WH-stabilized SS treatment showed the highest decreasing percent between the organic amendments.

These trends indicate that $\mathrm{B}, \mathrm{SBFL}$, and CFA were the best inorganic amendments in reducing DTPA-extractable $\mathrm{Cu}$ either in fluvial or calcareous soil. Bentonite-stabilized SS treatments showed a relatively high reduction of available $\mathrm{Cu}$ in both of the tested soils. This reduction may be due to the adsorption of $\mathrm{Cu}$ on the surface of bentonite or fixation of $\mathrm{Cu}$ as a result of precipitation, physical entrapment in clay lattice wedge zones, or strong adsorption at the exchange sites. The same conclusions are reported by Kabata-Pendias [3]. With respect to organic amendments, RS-stabilized SS treatment was the more suitable organic one for reducing DTPAextractable $\mathrm{Cu}$ in fluvial soil. The increase of RS efficiency of decreasing the available $\mathrm{Cu}$ may be due to the presence of high silicate amounts in RS [51]. This explanation was in agreement with [52] who reported that the presence of organic matter mixed with silicate (Si-organic form) can play an effective role in reducing the availability of heavy metals in polluted soils. This effect may be as the reaction of soluble silicate ions with the heavy metal (M) formed $\mathrm{M}-\mathrm{SiO}_{2}$ less or insoluble form. Also, metals reaction with organic materials forming complexing bonds.

The high ability of CFA in sorption of $\mathrm{Cu}$ in biosolidamended soil was studied by [30] who reported that application of CFA increased sorption of $\mathrm{Cu}$ about 7 times greater than the control. Water hyacinth was the best organic amendment for reducing DTPA-extractable $\mathrm{Cu}$ in calcareous soil. It may be due to its high content of organic matter. Copper is well known to be predominantly associated with soil organic matter (SOM) because of the high stability constants of its organic complexes [53].

Regarding the effect of incubation time, DTPA-extractable $\mathrm{Cu}$ decreased with increasing the incubation time. This trend was in agreement with [54] who found that concentrations of $\mathrm{Cu}$ and $\mathrm{Zn}$ declined progressively over the incubation; the decline was more pronounced for $\mathrm{Zn}$ than for $\mathrm{Cu}$. In regards to the effect of soil types, data in Table 6 indicated that the calcareous showed the best response for the effect of the tested amendments in decreasing DTPAextractable $\mathrm{Zn}$ compared to the fluvial soil.

\section{Conclusion}

The present study investigated the influence of sewage sludge and stabilized sewage sludge application on phosphorus availability and DTPA-extractable copper and zinc in relation to soil type, sewage source, mixing rate, and incubation time. Application of SS increased significantly Olsen-P compared to control. The increasing rates were higher in the case of domestic SS (SS2) compared to the industrial one (SS1), in the second incubation period ( 60 day) compared to the first one (30 day), and in calcareous soil compared to fluvial soil.
Mixing SS with the studied amendments increased Olsen-P especially SBFL- and WH-stabilized SS treatments.

Application of SS increased significantly DTPA-extractable Zn compared to control. Fluvial soil showed increasing rate higher than calcareous soil. Stabilization of SS by all the studied amendments reduced $\mathrm{Zn}$ availability except for cotton stalks treatment. Bentonite-, CFA- and RS-stabilized SS showed the highest decreasing rate of available $\mathrm{Zn}$. The highest application rate (i.e., \%25) was the best in reducing DTPA-extractable $\mathrm{Zn}$ either in the first or in the second incubation period. DTPA-extractable Zn decreased over incubation time. Fluvial soil showed the best response for the effect of the tested amendments on decreasing DTPA-extractable Zn compared to calcareous soil in both incubation periods.

Application of SS increased significantly DTPA-Cu rate with the industrial SS compared to the domestic one. Fluvial soil showed higher increasing rate than calcareous soil. Bentonite-, SBFL-, CFA RS, and WH-stabilized SS treatment showed the highest decreasing rate of available $\mathrm{Cu}$ in relation to SS. Stabilized sludge products reduced the availability of sludge trace elements, that is, copper and zinc, compared to the mono-SS treatments. Nevertheless, the long-term accumulation of trace elements following the application of stabilized sludge warrants further studies.

\section{References}

[1] R. P. Singh and M. Agrawal, "Potential benefits and risks of land application of sewage sludge," Waste Management, vol. 28, no. 2, pp. 347-358, 2008.

[2] C. D. Tsadilas, "Heavy metals forms in biosolids, soils and biosolid-amended soils," in Dynamics and Bioavailability of Heavy Metals in the Rootzone, H. M. Selim, Ed., pp. 271-291, CRC Press, Taylor and Francis Group, Boca Raton, Fla, USA, 2011.

[3] A. Kabata-Pendias, Trace Elements in Soils and Plants, CRC Press, Boca Raton, Fla, USA, 4th edition, 2011.

[4] D. C. Su and J. W. C. Wong, "Chemical speciation and phytoavailability of $\mathrm{Zn}, \mathrm{Cu}, \mathrm{Ni}$ and $\mathrm{Cd}$ in soil amended with fly ash-stabilized sewage sludge," Environment International, vol. 29, no. 7, pp. 895-900, 2004.

[5] USEPA, 40 CFR Part 503: Standards for the Use or Disposal of Sewage Sludge, U.S. Government Printing Office, Washington, DC, USA, 1997.

[6] R. O. Maguire, G. H. Rubæk, B. E. Haggard, and B. H. Foy, "Critical evaluation of the implementation of mitigation options for phosphorus from field to catchment scales," Journal of Environmental Quality, vol. 38, no. 5, pp. 19891997, 2009.

[7] G. A. O'Connor, D. Sarkar, S. R. Brinton, H. A. Elliott, and F. G. Martin, "Phytoavailability of Biosolids Phosphorus," Journal of Environmental Quality, vol. 33, no. 2, pp. 703-712, 2004.

[8] S. M. Shaheen, C. D. Tsadilas, and S. Stamatiadis, "Inorganic phosphorus forms in some entisols and aridisols of Egypt," Geoderma, vol. 142, no. 1-2, pp. 217-225, 2007.

[9] S. M. Shaheen, C. D. Tsadilas, and K. M. Eskridge, "Effect of common ions on phosphorus sorption and lability in Greek alfisols with different $\mathrm{pH}$," Soil Science, vol. 174, no. 1, pp. 2126, 2009. 
[10] S. M. Shaheen and C. D. Tsadilas, "Phosphorus sorption and availability to canola grown on an Alfisol amended with various soil amendments," Communication in Soil Science and Plant Analyses. In press.

[11] B. J. Alloway, Heavy Metals in Soils, Blackie Academic \& Professional, London, UK, 2nd edition, 1995.

[12] V. Antoniadis, C. D. Tsadilas, and V. Samaras, "Trace element availability in a sewage sludge-amended cotton grown Mediterranean soil," Chemosphere, vol. 80, no. 11, pp. 1308$1313,2010$.

[13] S. M. Shaheen and C. D. Tsadilas, "Fractionation and bioavailability of trace elements in biosolid amended Alfisol ten years after biosolids application," in Proceedings of the 11th International Conference of Bio-Geochemistry of Trace Elements, Florence, Italy, Joule 2011.

[14] S. M. Shaheen and C. D. Tsadilas, "Utilization of biosolids in production of bioenergy crops. I: Impact on canola biomass, soil properties and nutrient availability," Communication in Soil Science and Plant Analyses. In press.

[15] C. D. Tsadilas and S. M. Shaheen, "Utilization of biosolids in production of bioenergy crops. II: impact of application rate on bioavailability and uptake of heavy metals by canola," Communication in Soil Science and Plant Analyses. In press.

[16] R. A. El-Motaium and M. A. Abo El-Seoud, "Irradiated sewage sludge for production of fennel plants in sandy soil," Nutrient Cycling in Agroecosystems, vol. 78, no. 2, pp. 133-142, 2007.

[17] Soil Survey Staff, Keys to Soil Taxonomy, USDA-NRCS, Washington, DC, USA, 8th edition, 2010.

[18] G. W. Thomas, "Soil pH and soil acidity," in Methods of Soil Analysis, Part 3: Chemical Methods, D. L. Sparks, Ed., pp. 491516, Soil Science Society of America, Madison, Wis, USA, 1996.

[19] A. Walkley, "A critical examination of a rapid method for determining soil organic matter," Soil Science, vol. 63, pp. 654661, 1947.

[20] S. R. Olsen, C. V. Cale, F. S. Watanabe, and L. A. Dean, "Estimation of available phosphorus in soil by extraction with sodium bicarbonate," USDA Circular 939, 1954.

[21] J. Murphy and J. P. Riley, "A modified single solution method for the determination of phosphate in natural waters," Analytica Chimica Acta, vol. 27, pp. 31-36, 1962.

[22] (USEPA) United States Environmental Protection Agency, "Test methods for evaluating solid wastes," USEPA SW 846, U.S. Government Printing Office, Washington, DC, USA, 1995.

[23] W. L. Lindsay and W. A. Norvell, "Development DTPA soil test for Zink, iron, nickel, manganese, and copper," Soil Science Society of America Journal, vol. 42, pp. 421-428, 1978.

[24] G. W. Gee and J. W. Bauder, "Particle size analysis," in Methods of Soil Analysis: Physical and Mineralogy Methods. Part 1, A. Klute, Ed., pp. 383-412, ASA and SSSA, Madison, Wis, USA, 2nd edition, 1986.

[25] S. M. Shaheen, "Sorption and lability of cadmium and lead in different soils from Egypt and Greece," Geoderma, vol. 153, no. 1-2, pp. 61-68, 2009.

[26] European Community, "Council directive of 12 June 1986 on the protection of the environment, and in particular of the soil, when sewage sludge is used in agriculture: directive 86/276/EEC," Official Journal of the European Communities L, vol. 181, pp. 6-12, 1986.

[27] E. Dolsch, B. Deroche, and V. Van de Kerchove, "Impact of sewage sludge spreading on heavy metal speciation in tropical soils (Réunion, Indian Ocean)," Chemosphere, vol. 65, no. 2, pp. 286-293, 2006.
[28] D. C. Adriano, A. L. Page, A. A. Elseewi, A. C. Chang, and I. Straughan, "Utilization and disposal of fly ash and other coal residues in terrestrial ecosystems: a review," Journal of Environmental Quality, vol. 9, no. 3, pp. 333-344, 1980.

[29] D. El-Mogazi, D. J. Lisk, and L. H. Weinstein, "A review of physical, chemical, and biological properties of fly ash and effects on agricultural ecosystems," Science of the Total Environment, vol. 74, no. 1, pp. 1-37, 1988.

[30] C. Tsadilas, S. M. Shaheen, V. Samaras, D. Gizas, and Z. Hu, "Influence of fly ash application on Copper and Zinc sorption by acidic soil amended with biosolids," Communications in Soil Science and Plant Analysis, vol. 40, pp. 168-179, 2009.

[31] C. D. Tsadilas, S. M. Shaheen, V. Samaras, S. . Tang, and Z. $\mathrm{Hu}$, "Agricultural use of fly ash and sewage sludge and its impact on soil properties and bioavailability of heavy metals to wheat," in Proceedings of the 11th International Symposium on Soil and Plant Analysis, Santa Rosa, Calif, USA, July 2009.

[32] S. M. Shaheen and C. D. Tsadilas, "Influence of fly ash and sewage sludge application on cadmium and lead sorption by an acidic Alfisol," Pedosphere, vol. 20, no. 4, pp. 436-445, 2010.

[33] J. Dutton and J. E. Huijbregts, "Root quality and processing," in Sugar Beet, A. P. Draycott, Ed., pp. 409-442, Blackwell Publishing, Oxford, UK, 2006.

[34] S. Criquet and A. Braud, "Effects of organic and mineral amendments on available $\mathrm{P}$ and phosphatase activities in a degraded Mediterranean soil under short-term incubation experiment," Soil and Tillage Research, vol. 98, no. 2, pp. 164 174, 2008.

[35] J. W. C. Wong and D. C. Su, "Reutilization of coal fly-ash and sewage sludge as an artificial soil-mix: Effects of preincubation on soil physico-chemical properties," Bioresource Technology, vol. 59, no. 2-3, pp. 97-102, 1997.

[36] G. W. Smillie, D. Curtin, and J. K. Syers, "Influence of exchangeable Ca on phosphate retention in weakly acid soils," Soil Science Society of America Journal, vol. 51, no. 5, pp. 11691172, 1987.

[37] A. L. Sims, C. E. Windels, and C. A. Bradley, "Content and potential availability of selected nutrients in field-applied sugar beet factory lime," Communications in Soil Science and Plant Analysis, vol. 41, no. 4, pp. 438-453, 2010.

[38] A. R. A. Usman, Y. Kuzyakov, and K. Stahr, "Effect of clay minerals on extractability of heavy metals and sewage sludge mineralization in soil," Chemistry and Ecology, vol. 20, no. 2, pp. 123-135, 2004.

[39] S. R. Smith, "A critical review of the bioavailability and impacts of heavy metals in municipal solid waste composts compared to sewage sludge," Environment International, vol. 35, no. 1, pp. 142-156, 2009.

[40] L. Kiekens, "Zinc," in Heavy Metals in Soils, B. J. Alloway, Ed., pp. 284-305, Blackie Academic and Professional, London, UK, 2005.

[41] A. A. Zorpas, V. J. Inglezakis, and M. Loizidou, "Heavy metals fractionation before, during and after composting of sewage sludge with natural zeolite," Waste Management, vol. 28, no. 11, pp. 2054-2060, 2008.

[42] R. Ciccu, M. Ghiani, A. Serci, S. Fadda, R. Peretti, and A. Zucca, "Heavy metal immobilization in the miningcontaminated soils using various industrial wastes," Minerals Engineering, vol. 16, no. 3, pp. 187-192, 2003.

[43] C. D. Tsadilas, S. M. Shaheen, V. Samaras, and Z. Hu, "Influence of fly ash and sewage sludge application on 
the bioavailability and phytoextraction of heavy metals by Triticum Vulgare grown on acidic Alfisols," in Proceedings of the Cost Action 859-Meeting of Working Group 4, Verneuil-enHalatte, France, October 2008.

[44] H. Deng, Z. H. Ye, and M. H. Wong, "Accumulation of lead, zinc, copper and cadmium by 12 wetland plant species thriving in metal-contaminated sites in China," Environmental Pollution, vol. 132, no. 1, pp. 29-40, 2004.

[45] V. K. Mishra and B. D. Tripathi, "Accumulation of chromium and zinc from aqueous solutions using water hyacinth (Eichhornia crassipes)," Journal of Hazardous Materials, vol. 164, no. 2-3, pp. 1059-1063, 2009.

[46] A. R. A. Usman, Y. Kuzyakov, and K. Stahr, "Effect of immobilizing substances and salinity on heavy metals availability to wheat grown on sewage sludge-contaminated soil," Soil and Sediment Contamination, vol. 14, no. 4, pp. 329-344, 2005.

[47] Z. Hongling, S. Lina, and S. Tieheng, "Solubility of trace elements and heavy metals from stabilized sewage sludge by fly ash," Bulletin of Environmental Contamination and Toxicology, vol. 83, no. 5, pp. 752-756, 2009.

[48] A. M. Mahdy and E. A. Elkhatib, "Cadmium, copper, nickel, and lead availability in biosolids-amended alkaline soils," Australian Journal of Basic and Applied Sciences, vol. 1, no. 4, pp. 354-363, 2007.

[49] S. M. Shaheen, C. D. Tsadilas, T. Mitsibonas, and M. Tzouvalekas, "Distribution coefficient of Copper in different soils from Egypt and Greece," Communications in Soil Science and Plant Analysis, vol. 40, no. 1-6, pp. 214-226, 2009.

[50] L. M. Dudley, J. E. McLean, R. C. Sims, and J. J. Jurinak, "Sorption of copper and cadmium from the water-soluble fraction of an acid mine waste by two calcareous soils," Soil Science, vol. 145, no. 3, pp. 207-214, 1988.

[51] S. M. Shaheen, Pedo-chemical studies on some Egyptian soils under different depositional environments in relation to their heavy metals content, pollution and remediation [Ph.D. thesis], Faculty of Agriculture, Tanta University, Kafr El-Sheikh, EGYPT, 2005.

[52] S. B. Kanungo, "Leaching behavior of various trace metals in aqueous medium from two fly ash samples," Journal of Environmental Quality, vol. 29, no. 1, pp. 188-196, 2000.

[53] L. X. Zhou and J. W. C. Wong, "Effect of dissolved organic matter from sludge and sludge compost on soil copper sorption," Journal of Environmental Quality, vol. 30, no. 3, pp. 878-883, 2001.

[54] G. Murtaza, R. J. Haynes, R. Naidu et al., "Natural attenuation of $\mathrm{Zn}, \mathrm{Cu}, \mathrm{Pb}$ and $\mathrm{Cd}$ in three biosolids-amended soils of contrasting $\mathrm{pH}$ measured using rhizon pore water samplers," Water, Air \& Soil Pollution, pp. 1-13, 2011. 

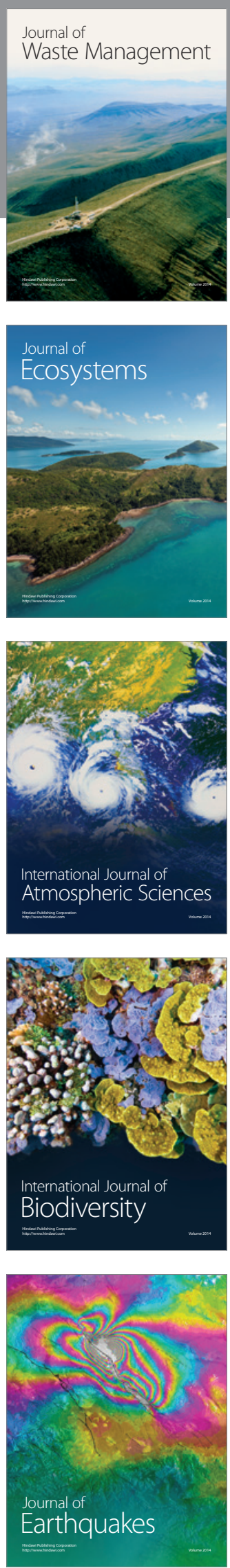
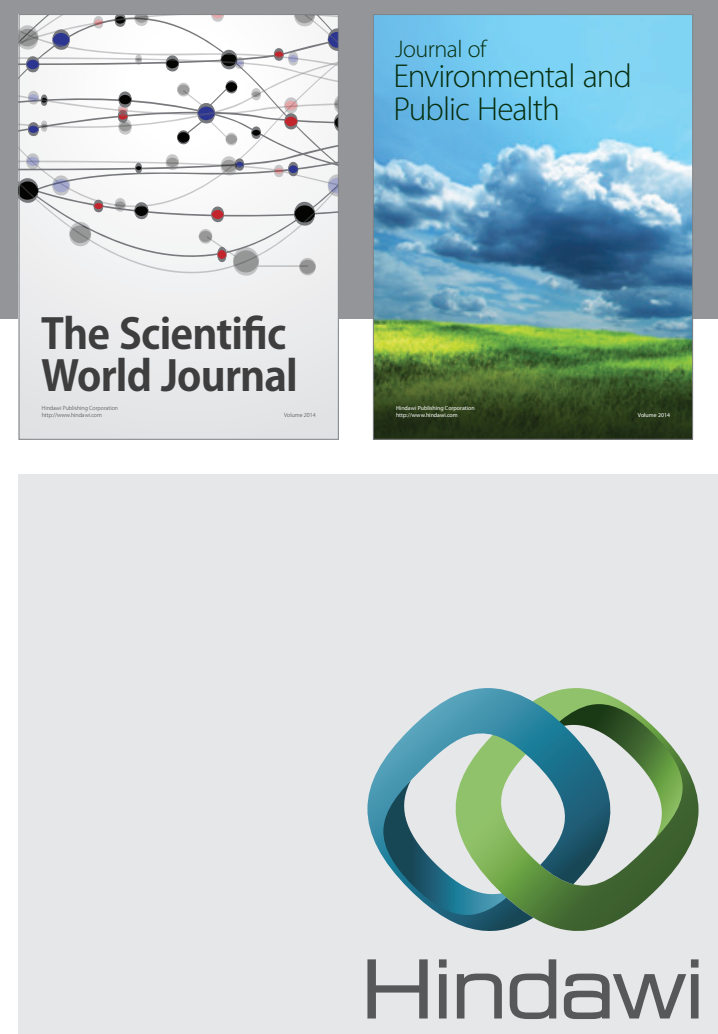

Submit your manuscripts at

http://www.hindawi.com
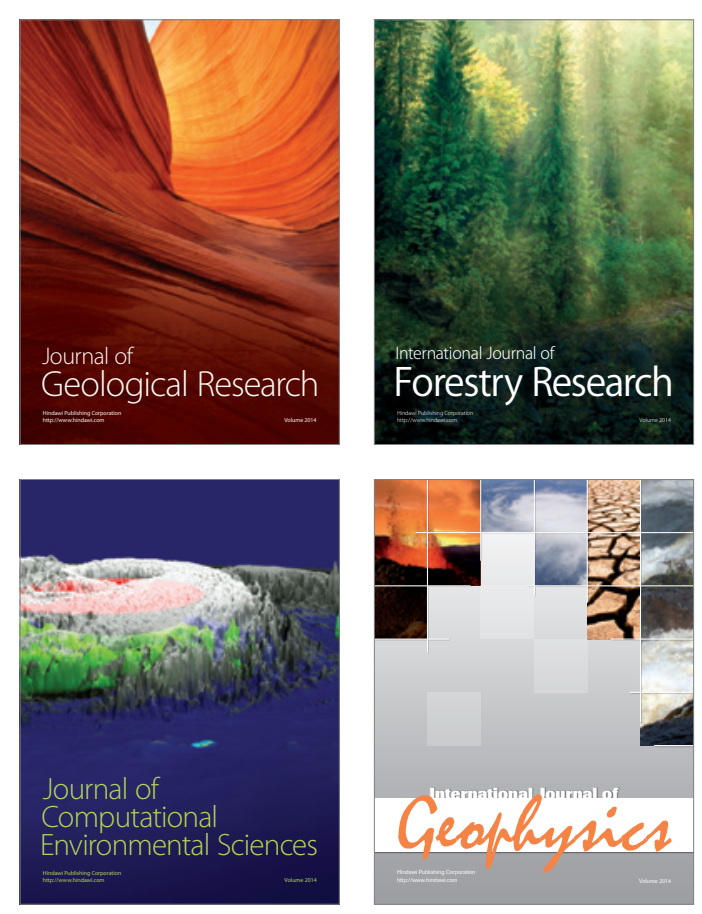
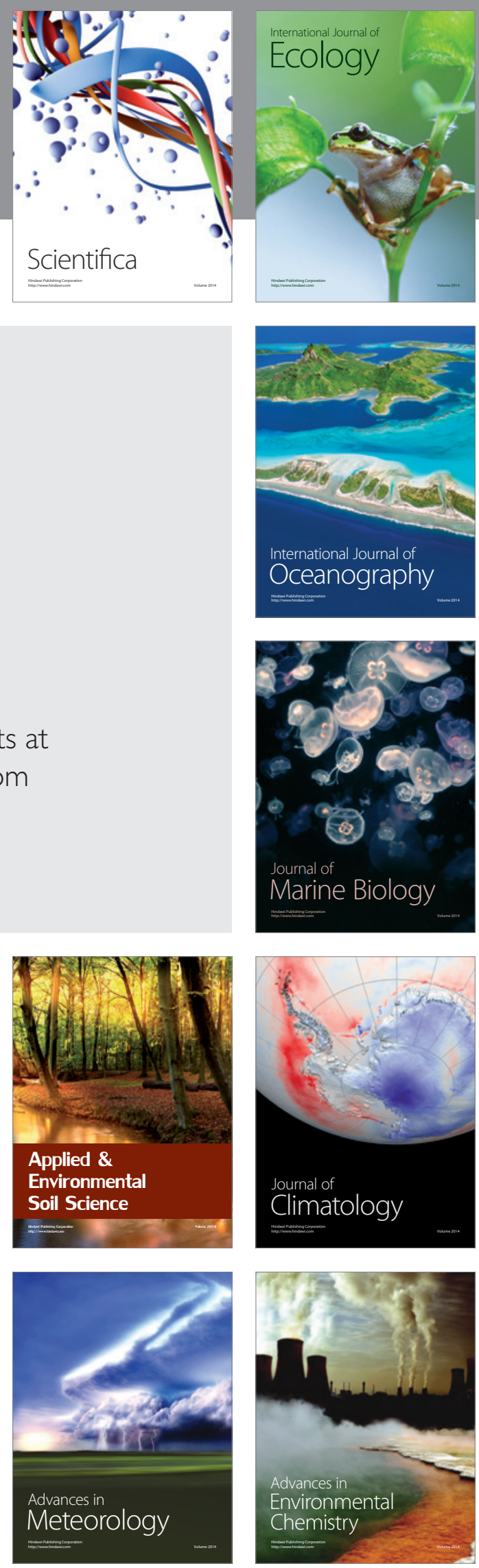